\title{
Snowbird Leadership Institute: Leadership Development in the Profession
}

\section{Teresa Y. Neely and Mark D. Winston}

\begin{abstract}
What is the impact of participation in leadership development programs in terms of career progression and involvement in leadership activities? To address this issue, individuals who had participated in the Snowbird Leadership Institute from its inception in 1990 to 1998 were surveyed regarding their career progression since their participation, their involvement in leadership activities, and their perceptions of the experience's impact on their careers. Although it is difficult to identify a direct relationship between participation in the Snowbird Leadership Institute and career progression and greater participation in leadership activities, the respondents did report an increased level of leadership activity. In addition, their perceptions of the institute's value with regard to their careers were largely positive and indicated that many of their career paths would have been different had they not had the Snowbird experience.
\end{abstract}

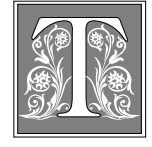

his research reflects the results of a study of individuals who participated in the Snowbird Leadership Institute from its inception in 1990 to 1998. The participants were asked about their career backgrounds and career progression subsequent to their participation in the institute, the level and type of their involvement in leadership and professional activities, and their perceptions of the Snowbird experience's impact on their career paths and progression. They also were asked to relate the importance of interaction with other participants and the program mentors to the value of the experience and to provide a number of demographic factors.

\section{Background and Review of the Literature}

A review of the literature reflects the increased emphasis on leadership in library and information science (LIS). Certainly, increased attention on this important issue is needed as academic libraries and librarians face challenges associated with information technology, human resources, and increased competition, among other factors. As Donald Riggs pointed out in a recent editorial in College $\mathcal{E}$ Research Libraries, "we may have been remiss in the past for not giving academic library leadership enough attention, but it will certainly be inexcusable if we continue to do so." 1 One important component of this discussion is the issue of leadership development and training.

Teresa Y. Neely is the Interim Personnel Librarian at Colorado State University Libraries; e-mail: tneely@manta.colostate.edu. Mark D. Winston is an Assistant Professor in the School of Communication, Information, and Library Studies at Rutgers University; e-mail: mwinston@scils.rutgers.edu. 
In an environmental scan of leadership development programs, the ARL's Office of Leadership and Management Services (ARL/OLMS) identified several such programs that met a number of guidelines for inclusion, such as "[T]he leadership program is a continuing offering, held regularly" and "[T]he focus of the program is on leadership development, not technical skills or policy analysis." ${ }^{2}$

The results of the environmental scan indicated that "In addition to ARL/OLMS programs, a wide variety of learning events are being offered by diverse organizations." ${ }^{3}$ It is important to note that several other organizations sponsor leadership development programs as well, including library consortia, state library associations, library schools, and individual universities.

The American Library Association (ALA), through the Association of College and Research Libraries (ACRL) and Library Administration and Management Association (LAMA), offer a number of programs geared to provide participants with an overview of leadership and the skills required to foster individual development. ${ }^{4}$

As has been suggested, leadership programs may focus on individuals at different stages of their careers. For example, the Senior Fellows program, "a biennial leadership and executive development experience," and the new ACRL/Harvard Leadership Institute, which has been "Developed for directors of libraries and those who report directly to them," ${ }^{5-6}$ represent offerings for those who are currently in senior administrative positions. The ARL Leadership and Career Development Program (ARL/LCDP) is a midto early career program "designed to increase the number of librarians from underrepresented racial and ethnic groups in positions of influence and leadership in research libraries by helping them develop the skills needed to be more competitive in the promotion process. ${ }^{17}$
In contrast, programs for those who are relatively new to the profession include the Snowbird Leadership Institute and the Northern Exposure to Leadership Program, the Canadian equivalent of Snowbird. ${ }^{8}$

The Snowbird Leadership Institute provides a leadership development opportunity for individuals in all types of libraries who are relatively new to their careers. Snowbird "is a five-day residential, primarily experiential, program of leadership training for people who are at a relatively early point in their library careers. This event takes place in August at a ski resort called Snowbird in the Wasatch Mountains rising above Salt Lake City."

According to F. William Summers and Lorraine Summers, who have been involved actively with the institute since its inception in 1990:

It is the brainchild of J. Dennis Day, [then] director of the Salt Lake City Public Library. Day was a strong supporter of 1987-88 American Library Association President Margaret Chisholm's call for special training for young leaders, and when ALA's proposal for a much broader project to carry this out was not funded, he decided to do something on his own. ${ }^{10}$

Since its inception, the institute has been funded in large measure by Ameritech (formerly, Dynix), under the leadership of its president, and now CEO, Paul Sybrowsky.

In an article on the first of the institutes, Nancy Tessman, then institute coordinator, described the program as "a series of experiences that encouraged self-exploration and discovery." ${ }^{11}$ It is structured on a number of learning activities, group activities, and interaction with mentors. The mentors have included "library school deans and faculty, directors of major public and academic libraries, and state librarians. The role of the mentors is to share their wisdom and experience 
with participants. They work and interact with learning groups and in one-onone situations throughout the [I]nstitute."12

Summers and Summers wrote that "If there is a key identifying concept of the Snowbird Leadership Institute it is probably the belief that being a leader depends as much as anything else upon knowing and being comfortable with who you are and having confidence in yourself."13 With thirty or so participants, normally with fewer than five years of experience following completion of the MLS degree, there is also the provision of "plenty of time for personal reflection and evaluation."14

According to Marilyn L. Miller, who has served as one of the program mentors:

The profession is empowered by Snowbird, because year after year a small group of emerging leaders joins a developing cadre of librarians who have had a vital leadership experience at a crucial time in their career and who are committed to professional growth. Snowbird also empowers the profession because it brings together librarians across all types of libraries and types of library functions and responsibilities to explore common interests, concerns, and opportunities. ${ }^{15}$

In their December 1991 article, Summers and Summers posed a significant question about Snowbird: "Will the annual output of thirty to thirty-five early to mid-career young people with special training make a difference in the quality and quantity of leadership in the field over time?"16 They suggested that with only two institutes completed, "it is too early to tell in any real sense." 17 The data and analysis presented here are intended to begin to answer that question, with a particular focus on a number of the leadership activities that are valued in academic libraries.

\section{General Methodology}

This paper presents the findings of a research study of individuals who have participated in the Snowbird Leadership Institute. The primary focus of this original research is to analyze the impact of the knowledge and insight gained on the career progression and professional activities of the participants, as well as specific knowledge and skills gained as a result of participation. Survey methodology was used, and data were collected by direct-mailing the questionnaire to every known Snowbird participant.

\section{Instrumentation}

The survey instrument used in this study was designed to address issues related to demographics, educational background, work experience prior to entering librarianship, and professional experience before and after participating in the institute. It was adapted from two instruments: one used in a 1997 research study, and one used in a 1997 dissertation. The former was used in a study reported on by Julie A. Brewer in the November 1997 issue of College $\mathcal{E}$ Research Libraries. ${ }^{18}$ Designed by the ALA's Office for Library Personnel Resources (OLPR) on postmaster's residency programs, this instrument was designed to "gather information about residency experiences from the perspective of former program participants." ${ }^{19}$ The latter instrument was used in Mark D. Winston's 1997 dissertation, which investigated the role of recruitment in the education and careers of academic business librarians. ${ }^{20}$ The resulting survey instrument was expanded to make allowances for the leadership activities of both academic and public librarians and for the Snowbird population.

The Winston instrument provided the basic structure for the Snowbird Leadership Institute instrument. Basic demographic queries and items on educational background were either taken directly from this instrument or adapted from it.

The Snowbird survey adapted a number of relevant areas from the Brewer/ OLPR instrument, such as queries re- 
questing the year of participation and the individual who nominated the respondent for participation. The professional and career development section of the Brewer/OLPR instrument provided the basis for a similar section in the Snowbird instrument relating to the participants' perception of Snowbird's overall impact on their careers and professional development. Following this section, the Snowbird instrument included items constructed to gather information on specific aspects of the Snowbird experience that continued after the institute itself. Items in the summary section of the Brewer/ OLPR instrument were adapted to construct queries about the participants' status before and after the institute.

Both researchers have academic library backgrounds and, therefore, have defined and interpreted leadership activities as research (i.e., publications and presentations) and service, including participation in committees and professional/scholarly associations. Their survey instrument included an item (26) that asked about other leadership activities; however, many respondents from public librarianship were critical of the survey's academic slant and implied that the inclusion of item 26 and other items as the sole mechanisms for collecting additional qualitative data were inadequate. Thus, this discussion of the survey results focuses on those measures of leadership that are likely to be more highly valued in academic libraries.

Before the survey was distributed, it was reviewed by institute administrators and consultants, and an e-mail message was sent to the Snowbird listserv announcing the intended research, explaining that the surveys would be arriving shortly, and encouraging the return of completed surveys. ${ }^{21}$ In October 1998, the surveys, along with a cover letter and a self-addressed, return envelope, were mailed to the entire population of individuals $(n=213)$ on the most current list of Snowbird Leadership Institute participants (1990-1998) as obtained from the Salt Lake City headquarters. ${ }^{22}$ (Postage was not included, although at least one participant felt this would have been a welcome addition and may contribute to a higher response rate.) In mid-November, a follow-up mailing was done.

In total, 150 usable surveys were returned, reflecting a response rate of nearly 71 percent. Thirteen surveys were returned by the postal service as a result of noncurrent addresses, and one was returned with a note from the respondent but was not completed. The latter survey and surveys returned incomplete were included in the response rate, and the data on incomplete surveys (those where the participants skipped items or pages of items) were included in the data analysis. Although a large amount of data was collected, this paper presents only relevant selected findings related to the demographic profile of the population, educational backgrounds, leadership activities, and career progression and development. A more complete discussion of the leadership activities identified by the public library respondents is forthcoming.

\section{Selected Findings and Discussion}

The researchers' intent to collect relevant data from all participants from 1990 to 1998 took into consideration that the 1997 class was a reunion year and did not include new participants. Moreover, the instrument did not make allowances for 1998 participants, who, having only recently completed the institute, could not adequately answer all of the queries. As a result, the 1998 participants are discussed where relevant. All statistical analysis was done with an $n=150$ scale, and throughout much of the analysis, null and N/A responses are reported where appropriate.

Of the 150 usable surveys, 1994 and 1998 classes showed the highest return rate, as shown in table 1.

\section{Demographics}

The population is somewhat homogeneous in that it is predominantly white $(85.33 \%)$, female $(76 \%)$, and in the $40+$ age range $(55 \%)$, although nearly 24 per- 


\begin{tabular}{|c|c|c|}
\hline \multicolumn{3}{|c|}{$\begin{array}{c}\text { TABLE } 1 \\
\text { Breakdown of Usable Returned } \\
\text { Surveys by Year of Attendance }\end{array}$} \\
\hline Year & $\begin{array}{c}\text { No. of Usable } \\
\text { Surveys Received }\end{array}$ & $\%$ \\
\hline 1990 & 11 & $7.3 \%$ \\
\hline 1991 & 14 & $9.3 \%$ \\
\hline 1992 & 22 & $14.6 \%$ \\
\hline 1993 & 11 & $7.3 \%$ \\
\hline 1994 & 25 & $16.66 \%$ \\
\hline 1995 & 21 & $14 \%$ \\
\hline 1996 & 17 & $11.3 \%$ \\
\hline 1998 & 25 & $16.66 \%$ \\
\hline & 4 & $2.66 \%$ \\
\hline Total & 150 & \\
\hline
\end{tabular}

cent reported their age as between 31 and 35 . As table 2 shows, 148 respondents reported their gender and ethnicity, and 145 reported their age range. The ethnic background section of table 2 shows three respondents in the "Other" category. Of these, one ethnic background was reported as white Australian; a second was reported as U.S. citizen, Jamaican heritage; and a third was not reported.

Because the focus of this paper is leadership activities, with a particular focus on academic librarianship, it is appropriate to view the academic librarian subset of the Snowbird population in comparison to the other members of that population. Tables 3 and 4 reflect the comparison with regard to gender, age, and ethnic background. Table 3 shows that academic librarians make up 38 percent of the total population, with more than 70 percent of that group being women. As in the total population, white women in the $40+$ categories are the largest group.

\section{Academics}

Undergraduate Careers. Academic background was of interest to the researchers as a part of providing a complete profile of the Snowbird participants. All but four of the respondents reported having an undergraduate degree and their major subject area. Nearly 23 percent (34) reported English as their undergraduate major. Other subject areas worth noting include history $(8 \%)$, social sciences and other $^{23}(7.3 \%$ each), and fine arts and business (6.6\% each). More than 50 percent (92) of the respondents reported not having an undergraduate minor. Three persons reported library science as an undergraduate minor.

MLS/MLIS and Other Graduate Degrees. The terminal degree for the LIS profession is considered by the ALA and the majority of the profession to be the master's degree. Findings in this area, 96.66 percent, overwhelmingly confirm this assumption. However, 2 percent (3) of the respondents reported not having earned the degree and 1.3 percent (2) did not answer the question.

Almost 77 percent (115) of the respondents reported not having earned an additional graduate degree at the time of the survey. Thirty of the Snowbirders have earned master's degrees, three have earned doctorates, and one has earned the

\begin{tabular}{|c|c|c|c|c|c|}
\hline \multicolumn{6}{|c|}{$\begin{array}{c}\text { TABLE } 2 \\
\text { Gender, Ethnic Background, and Age Range of Snowbird Population }\end{array}$} \\
\hline \multicolumn{2}{|c|}{ Gender } & \multicolumn{2}{|l|}{ Ethnic Background } & \multicolumn{2}{|c|}{ Age Range } \\
\hline Femal & 114 & White & 128 & $21-25$ & 0 \\
\hline Male & 34 & Black/African American & 11 & $26-30$ & 9 \\
\hline \multirow[t]{4}{*}{ Null } & 2 & Hispanic/Latino & 3 & $31-35$ & 35 \\
\hline & & Other & 3 & $36-39$ & 17 \\
\hline & & Asian/Asian American & 2 & $40-45$ & 38 \\
\hline & & American Indian-Native American & 1 & $46+$ & 46 \\
\hline
\end{tabular}




\begin{tabular}{|lccccc|}
\hline \multicolumn{5}{|c|}{$\begin{array}{c}\text { TABLE 3 } \\
\text { Comparison of Gender and Age Range between } \\
\text { Academics and Nonacademics }\end{array}$} \\
\hline \hline Gender & Academics & Non & Age Range & Academics & Non \\
\hline Female & 41 & 72 & $21-25$ & 0 & 0 \\
Male & 16 & 18 & $26-30$ & 5 & 4 \\
Null & 0 & 2 & $31-35$ & 14 & 21 \\
& & & $36-39$ & 9 & 8 \\
& & & $40-45$ & 11 & 27 \\
& & & $46+$ & 18 & 27 \\
& & & Null & & 5 \\
\hline Total & 57 & 92 & & 57 & 92 \\
\hline
\end{tabular}

In terms of professional experience, the participants have been librarians for an average of eight years (table 5). More than half the respondents have been professional librarians for between six and ten years, and slightly more than onequarter have had

equivalent of a master's degree in education. Almost 27 percent (40) of the respondents reported that they had completed additional graduate credits in a variety of disciplines that had not been applied toward a degree.

\section{Career Background and Progression}

An important component of the profile of the Snowbird Leadership Institute participants is a discussion of career backgrounds and career progression since participation in the institute, as well as the level and type of involvement in leadership and professional activities.

Career Progression. Certainly, a significant part of this discussion centers on the respondents' perceptions of the impact of the Snowbird experience on their career paths and progression. This discussion includes information on years of professional library experience, years of prior experience in other professions, and years as paraprofessionals in libraries. It also includes the types of libraries in which they worked at the time of their attendance and at present, the types of positions they have held and currently hold, and career progression since participation in the institute. five or fewer years of professional experience. In contrast, with regard to when they participated in Snowbird, the respondents indicated that they had had an average of just under four years of professional library experience, reflecting the program focus on individuals who are relatively new to the profession. In fact, 85 percent had had five or fewer years of professional experience at the time of participation.

With regard to the types of libraries in which they have been employed, nearly all of the Snowbird participants had worked in either public libraries $(66$, or $44 \%$ ) or academic libraries (52, or $34.66 \%$ ) at the time they attended the institute (table 6). Of those who indicated the type of library in which they currently are working, $44(29.33 \%)$ stated public and 25 $(16.66 \%)$ stated academic. However, providing a comparison of the types of librar-

\section{TABLE 4}

\section{Comparison of Ethnic Background between Academics and Nonacademics}

\begin{tabular}{lcc}
\hline Ethnic Background & Academics & Nonacademics \\
\hline White & 49 & 78 \\
Black/African American & 6 & 5 \\
Hispanic/Latino & 2 & 1 \\
Other & 0 & 3 \\
Asian American & 0 & 22 \\
American Indian/Native American & 0 & 1 \\
Null & 0 & 2 \\
\hline Total & 57 & 92 \\
\hline
\end{tabular}


TABLE 5

Professional Experience Currently and During Snowbird

\begin{tabular}{l|c|c|c|c}
\hline \hline \multirow{2}{*}{ Years of Experience } & \multicolumn{2}{|c|}{ Currently } & \multicolumn{2}{c}{ During Snowbird } \\
\hline $0-5$ years & 39 & $26 \%$ & 128 & $85.33 \%$ \\
$6-10$ years & 83 & $53.33 \%$ & 10 & $6.66 \%$ \\
$11-15$ years & 14 & $9.33 \%$ & 4 & $2.66 \%$ \\
$16-20$ years & 8 & $5.33 \%$ & 4 & $2.66 \%$ \\
More than 20 years & 3 & $2 \%$ & 0 & \\
No response & 3 & $2 \%$ & 4 & $2.66 \%$ \\
\hline
\end{tabular}

were at the time of their participation in the institute are in academic libraries, with approximately one-quarter in public libraries, reflecting moves to or among academic library positions. ies in which respondents were working at the time of their participation and the types in which they currently are working is difficult because one-third of the respondents did not provide the latter information. That such a large percentage of respondents did not answer this survey item may be due to the fact that an earlier question addressed their current job situation in reference to their Snowbird participation. In fact, 38.66 percent indicated that they are in the same position (and at the same institution) now as they were when they attended the institute. Another 25.33 percent reported being in the same institution, but in a different position. It should be noted that some respondents selected more than one category in response to this item.

In fact, of the fifty-eight respondents who indicated being in the same position currently that they were in at the time of the institute, half (51.72\%) are working in public libraries. Nearly a third are in academic libraries, with 10.34 percent in government libraries and approximately five percent in special libraries. In contrast, a slightly larger percentage $(55.26 \%)$ of those who are working in the same institution, but in a different position, are in public libraries, with fewer $(23.68 \%)$ in academic libraries. It should be noted that almost half of those who are working in different institutions than they
It is interesting to note the changes in type of position held by the respondents now as compared to their time of participation. More than a third (58, or $38.66 \%)$ of the respondents were working in public services at the time of their participation in the institute (table 7). With regard to administrative positions, $34(22.66 \%)$ were department heads or heads of branches, $18(12 \%)$ were directors or deans, and $5(3.33 \%)$ were assistant or associate deans or directors. Only 15 $(10 \%)$ were working in technical services, and $21(14 \%)$ were working in other LIS areas. In contrast, only $30(20 \%)$ are working in public services now, and slightly fewer $(13$, or $8.6 \%$ ) reported working in technical services now, as compared to their positions at the time of participation in the institute. As would be expected on the basis of the fact that they have been in the profession for a greater period of time, more of the survey respondents are now in administrative positions. At present, $46(30.6 \%)$ are heads of branches

\begin{tabular}{lcc} 
Position Type & Currently & During Snowbird \\
\hline Academic & 25 & 52 \\
Public & 44 & 66 \\
Special & 5 & 8 \\
Government & 7 & 12 \\
School & 0 & 1 \\
Other & 7 & 10 \\
Not working in a library & 12 & 3 \\
No response & 50 &
\end{tabular}

\begin{tabular}{c} 
TABLE 6 \\
$\begin{array}{c}\text { Employing Institution Currently } \\
\text { and During Snowbird }\end{array}$ \\
\hline \hline
\end{tabular}




\begin{tabular}{|c|c|c|}
\hline \multicolumn{3}{|c|}{$\begin{array}{c}\text { TABLE } 7 \\
\text { Type of Position Held Currently } \\
\text { and During Snowbird }\end{array}$} \\
\hline Position Type & Currently & During Snowbird \\
\hline Public services & 30 & 58 \\
\hline Technical services & 13 & 15 \\
\hline Department or branch head & 46 & 34 \\
\hline Asst. or assoc. dean/ director & 10 & 5 \\
\hline Dean/director & 22 & 18 \\
\hline Other & 26 & 21 \\
\hline No response & 3 & 2 \\
\hline
\end{tabular}

the level of leadership activity before and after participation in the institute is an important element in considering the institute's role in the respondents' careers.

With respect to career background prior to entering librarianship, more than 60 percent reported holding paraprofessional positions in LIS. Of those, the aver-

of departments, $10(6.66 \%)$ are assistant or associate deans or directors, and 22 $(14.6 \%)$ are deans or directors. Certainly, it is impossible to draw a direct correlation between the respondents' participation in the leadership institute and their career and upward mobility, but discussion of their perceptions of both the impact of their participation on obtaining subsequent positions and whether their careers (discussed below) would have been different had they not had the Snowbird experience provides additional information about the institute's role.

\section{Certainly, it is impossible to draw a direct correlation between the respondents' participation in the leadership institute and their career and upward mobility.}

Although it is important to consider the promotions and what appears to be the upward mobility of those who have participated in the institute, it should be noted that not all progression is vertical. Thus, being promoted or obtaining a higher-level position elsewhere is not the only measure of career progression. Moreover, the size and availability of promotion opportunities in the employing institution and the relative mobility of the respondents also are factors. (Factors such as these are outside the scope of this study.) In addition, some of the respondents were already in administrative or managerial positions at the time of participation. Of course, the comparison of age number of years reported was 6.4, reflecting the fact that $52(34.6 \%)$ of the respondents had five or fewer years of paraprofessional experience in LIS and 29 $(19.33 \%)$ had six to ten years of such experience (table 8 ). In contrast, slightly less than one-quarter $(22 \%)$ reported holding positions in some other field prior to becoming librarians. And those who had worked in other fields before entering librarianship had done so for relatively short periods of time. In fact, 128 (85\%) of those who had worked in other fields had five or fewer years of such experience, with the average being 3.84 years.

Leadership Activities. One limitation of the study centers on the discussion of leadership activities. Because the two researchers either are working or have worked in academic library settings, the leadership activities the respondents were queried about reflect an emphasis on activities that are often expected of academic librarians. This may reflect a greater degree of activity in these types of settings

\section{TABLE 8}

\section{Paraprofessional Experience}

\begin{tabular}{lrc} 
Years of Experience & LIS & Other Fields \\
\hline $0-5$ years & 52 & 128 \\
6-10 years & 29 & 10 \\
$11-15$ years & 12 & 4 \\
16-20 years & 3 & 4 \\
More than 20 years & 3 & 0 \\
No response & 51 & 4 \\
\hline
\end{tabular}


than would be the case for survey participants working in public, school, or special libraries. Thus, the respondents were asked to indicate other leadership activities in which they have been involved.

The leadership activities considered in-

\begin{tabular}{|lcc|}
\hline \multicolumn{3}{|c|}{$\begin{array}{c}\text { TABLE 9 } \\
\text { Leadership Activities: } \\
\text { Respondents Reporting Publication Activity }\end{array}$} \\
\hline \hline Publication Types & $\begin{array}{c}\text { No. of Respondents } \\
\text { before Snowbird }\end{array}$ & $\begin{array}{c}\text { No. of Respondents } \\
\text { after Snowbird }\end{array}$ \\
\hline Journal articles & 36 & 49 \\
Books & 12 & 17 \\
Book chapters & 18 & 33 \\
Book reviews & 18 & 46 \\
Conference papers & 20 & 25 \\
\hline
\end{tabular}
cluded scholarly activities such as research, publication, and presentations. To consider the impact of the institute on their level of professional activity, the respondents were asked to indicate their level of scholarly activity before and after attending the institute. Any discussion of these factors must take into consideration the fact that professional longevity is likely to have some impact on the participant's level of scholarly and professional activity. In addition, the fact that the institute focuses on leadership development for those who are at relatively early stages in their career suggests that at the time of participation, the level of activity reported was not likely to be directly comparable to the level reported later. It should be noted that only 15 percent of the respondents indicated that they are required to write, publish, and/ or engage in research in order to obtain promotion and/or tenure or a tenure equivalent. Fewer $(12 \%)$ have held other positions with these requirements since participating in Snowbird.

The data gathered reflect the respondents' publication activity in terms of journal articles, books, book chapters, book reviews, and publications in conference proceedings.

Of the 150 respondents, only thirty-six had authored or coauthored articles published prior to participating in Snowbird (table 9). Since their participation in the institute, there has been a 15.29 percent increase in the number of respondents who have published articles. Greater increases are reflected for all other types of publications as well. Not surprisingly, the largest increase $(43.75 \%)$ is seen in the number of respondents who have written book reviews. However, it should be noted that a larger number of individuals wrote journal articles than book reviews.

In terms of academic librarians versus nonacademics, in every category, the number of publications increased, significantly in some cases, with the exception of journal articles for nonacademics (table

\begin{tabular}{|c|c|c|c|c|}
\hline \multicolumn{5}{|c|}{$\begin{array}{c}\text { TABLE } 10 \\
\text { Leadership Activities Comparison of Publications for } \\
\text { Academics and Nonacademics } \\
\end{array}$} \\
\hline \multirow[t]{2}{*}{ Publication Types } & \multicolumn{2}{|c|}{ Academics } & \multicolumn{2}{|c|}{ Nonacademics } \\
\hline & Before & After & Before & After \\
\hline Journal articles & 13 & 28 & 30 & 29 \\
\hline Books & 1 & 4 & 11 & 12 \\
\hline Book chapters & 3 & 23 & 7 & 18 \\
\hline Book reviews & 27 & 75 & 40 & 101 \\
\hline Conference papers & 6 & 8 & 9 & 15 \\
\hline Total & 50 & 138 & 92 & 169 \\
\hline
\end{tabular}


TABLE 11

Leadership Activities: Respondents Reporting Presentation Activity

\begin{tabular}{lcc} 
Conferences & $\begin{array}{c}\text { No. of Respondents } \\
\text { before Snowbird }\end{array}$ & $\begin{array}{c}\text { No. of Respondents } \\
\text { after Snowbird }\end{array}$ \\
\hline National or international library conferences & 30 & 50 \\
State/regional library conferences & 63 & 84 \\
Other library conferences & 40 & 63 \\
Other conferences & 54 & 81
\end{tabular}

10). Overall, publications for academics increased more than 175 percent, with an 83 percent increase for nonacademics. Book reviews increased by 177 percent and book chapters by 666 percent for academics. In contrast, journal articles for nonacademics decreased, and book publication increased by only 0.38 percent. The greatest increase for nonacademics was in book reviews, at nearly 23 percent.

A more consistent level of increase was noted in presentations reported. The participants were asked about presentations they had made at professional library conferences at the national, international, and state levels, and other library conferences and conferences in other disciplines. As table 11 shows, the increases ranged from 33 to 66 percent, with the greater increase being for respondents who had given presentations at national and international library conferences (even though the largest number of respondents had presented at state library association conferences).
Table 12 shows similar data for the academic subset compared to the group of nonacademics. Levels of participation (i.e., number of presentations) at national or international conferences decreased in both subsets. However, presentations at all other conferences increased for both academics and nonacademics.

\section{Attitudes about the Institute and Perceived Impact}

To gather data on the participants' attitudes about the institute, the researchers asked participants what impact the institute has had on their career progression, what they have learned through interaction with other Snowbird participants, and what benefits they have derived from the institute itself. Forty percent of the respondents reported that the institute contributed somewhat to their obtaining subsequent positions, and 19 percent reported that it contributed to a great extent. However, 31.33 percent (47) reported that it did not contribute at all to subse-

\begin{tabular}{|c|c|c|c|c|}
\hline \multicolumn{5}{|c|}{$\begin{array}{c}\text { TABLE } 12 \\
\text { Leadership Activities: Comparison of Presentations for } \\
\text { Academics and Nonacademics } \\
\end{array}$} \\
\hline \multirow[t]{2}{*}{ Conferences } & \multicolumn{2}{|c|}{ Academics } & \multicolumn{2}{|c|}{ Nonacademics } \\
\hline & Before & After & Before & After \\
\hline $\begin{array}{l}\text { National or international } \\
\text { library conferences } \\
\text { State/regional library }\end{array}$ & 28 & 5 & 58 & 42 \\
\hline Conferences & 23 & 48 & 117 & 148 \\
\hline Other library conferences & 18 & 33 & 52 & 122 \\
\hline Other conferences & 23 & 113 & 399 & 1,090 \\
\hline Total & 92 & 199 & 626 & 1,402 \\
\hline
\end{tabular}


quent positions. The latter statistic is in line with the 38.66 percent (58) who reported that at the time of the survey, they were in the same position as when they attended the institute.

In a question related to career progression, nearly half the respondents $(48.66 \%$, or 73) selected yes when asked if they believed their career paths would have been different without the Snowbird experience. Forty-two percent answered that it would not have been different, and fourteen respondents declined to answer the question.

Individuals who have participated in the institute are selected from a larger pool and, ostensibly, are the cream that rose to the top during the selection process. With this in mind, the researchers included queries to gather data on learnings and interactions with other Snowbird participants. Seventy-six percent (114) of those surveyed noted that interaction with other participants contributed a great deal to the overall quality and experience of the institute, 22 percent noted that it contributed to some extent, and one person reported that interactions with other participants did not contribute at all to the overall quality of the experience.

Recognizing the proprietary nature of the content and curriculum of the institute itself, the researchers generalized the overall Snowbird experience, including all learning techniques, literature, and structured group and individual occurrences, by asking respondents about the perceived benefits and learnings from activities that occurred after the institute. The survey instrument included a num- ber of opportunities for gathering qualitative data about the institute, and these data will be analyzed and disseminated at a later date. Four categories of post-institute activity were identified, and participants were surveyed using multiplechoice queries modeled on a Likert scale.

Listserv. The Snowbird listserv is an electronic discussion list, open only to Snowbird participants. Selection and participation in the institute does not guarantee automatic sign-up; many respondents expressed a lack of knowledge about the existence of the listserv, and some included requests in their comments to be subscribed. Several offered comments about the traffic on the listserv, including its perceived primary existence as a method for announcing job and address changes, as opposed to being a tool for discussion of leadership and related issues. As primarily a lurker on this listserv, one of the researchers observed that there have been attempts to introduce and sustain stimulating and intellectual discussions; however, it is difficult for one or two persons to provide the continuing dialogue for an entire list. Table 13 shows the responses about the listserv and the other categories-informal reunions at professional conferences, collegial relationships developed with other participants, and mentoring relationships.

Informal Reunions. The Snowbird Leadership office in Salt Lake City hosts an annual reception for participants and mentors at the ALA's annual conference each

\begin{tabular}{|cclll|}
\hline \multicolumn{5}{c}{ TABLE 13 } \\
Responses for Categories Identified as Post-institute Relevant Activities \\
\hline \hline $\begin{array}{c}\text { Contributions to } \\
\text { Individual Benefits } \\
\text { and Learning }\end{array}$ & Listserv & $\begin{array}{c}\text { Informal } \\
\text { Reunions }\end{array}$ & $\begin{array}{c}\text { Collegial } \\
\text { Relationships }\end{array}$ & Mentoring \\
\hline To a great extent & $15(10 \%)$ & $14(9.33 \%)$ & $35(23.33 \%)$ & $26(17.33 \%)$ \\
To some extent & $57(38 \%)$ & $47(31.33 \%)$ & $79(52.66 \%)$ & $61(40.60 \%)$ \\
Not at all & $69(46 \%)$ & $62(41.33 \%)$ & $31(20.66 \%)$ & $57(38 \%)$ \\
No response & $9(6 \%)$ & $27(18 \%)$ & $5(3.33 \%)$ & $6(4 \%)$ \\
\hline
\end{tabular}


summer. Depending on the location of ALA's midwinter conference and/or division conferences (e.g., Public Library Association, Association of College and Research Libraries, and so on), local participants sometimes organize dinners, lunches, or other informal meetings for Snowbirders attending those conferences. Table 13 shows that almost 41 percent of the respondents reported that these informal reunions contribute to a great extent or to some extent to the overall quality of their post-institute interaction. Nearly 60 percent (89 respondents) either did not answer or reported that these reunions did not contribute to the quality of the experience. An analysis of the years of participation of the eightynine respondents did not reveal any statistically significant relationship between year of participation and attitude about informal reunions.

\section{It is difficult to identify a direct relationship between participation in the Snowbird Leadership Institute and career progression and greater participation in leadership activities.}

Collegial Relationships. Collegial relationships were identified as an area for further analysis because the researchers recognize their importance in the profession of librarianship. Collegial relationships are developed and maintained via listservs, at annual and biannual conferences, and via other professional development opportunities. Networking, professionally and socially, has long been associated with advancement in the corporate, private, public, and higher education sectors. Table 13 reveals that collegial relationships have contributed greatly or to some extent to the quality of the experience for 114 (76\%) of the participants.

Mentoring Relationships. Mentoring is an important component of the Snowbird experience. In fact, in most of the leadership institutes previously discussed, mentoring is given much con- sideration. The mentoring aspect of the institute was more informal in that, for the duration of the institute, small groups of individuals were assigned to two mentors. These relationships have the potential to continue after the institute, but this post-institute activity is not directly structured. Mentors have ranged from lawyers to directors of large public library systems to library administrators from universities, both public and private. Table 13 shows that almost 58 percent (87) of those responding to the survey rated mentoring relationships as contributing to a great extent or to some extent to the quality of their Snowbird experience. Thirtyeight percent of those surveyed reported that the mentoring relationships did not contribute to the quality of their experience, and four percent did not answer the question. The fact that a significant portion of the population did not rate the value of the mentoring relationships highly may be due to the lack of individual mentoring relationships or may be a factor of the population demographics and the difficulty of building such relationships.

Other Library Leadership Programs. The researchers' interest in the effects of library leadership programs led to an inquiry about participation in other library leadership programs. Twenty-two respondents mentioned participation in other institutes, citing state or regional leadership programs. Seventy-eight percent reported that they had not participated in any other programs, eight percent reported they had attended the ALA Emerging Leaders Institute, and six percent reported they had recently participated in the ARL Leadership and Career Development Program. Although the former institute appears to have been a one-time opportunity, plans are under way for a second ARL program; and as participants in the latter, the researchers look forward to examining that population for trends and evidence of acquired outcomes. 


\section{Summary and Recommendations for Future Research}

It is difficult to identify a direct relationship between participation in the Snowbird Leadership Institute and career progression and greater participation in leadership activities. However, it is clear that the respondents report an increased level of activity in a number of different categories of leadership activity. In addition, their perceptions of the institute's value with respect to their career progression are largely positive and indicate that many of their career paths would have been different had they not had the Snowbird experience.

In terms of the respondents' attitudes about the institute's perceived impact, it is difficult to determine the relationship between the impact of the institute and the attainment of subsequent positions. The fact that nearly 40 percent reported that they are currently in the same position as when they attended the institute does not allow a clear analysis of this particular occurrence. However, other activities engaged in while remaining in the same position may begin to shed some light on this aspect of the study; and, as mentioned previously, the number of individuals increased in every category in the presentation and publication categories.
Interactions with other Snowbird participants (categorized as collegial relationships) and mentoring are highly rated by most participants, although 38 percent answered that mentoring did not contribute to the quality of their overall experience. As previously mentioned, mentoring is critical, and the informal, unstructured approach may not have been the best method for introducing the mentoring component.

The listserv and informal reunions were not highly rated. This could be due to the informal nature of both or the fact that not all of the former participants attend professional conferences where the reunions are held.

The researchers recommend further analysis of the data collected, with special emphasis on the qualitative responses to the queries on leadership, career progression, and impact of the institute on individual careers. Moreover, it would be beneficial to track the participants of the Spectrum Initiative, the ALA's recruitment and scholarship program, for more in-depth qualitative data on the mentoring component and the proposed leadership program for Spectrum participants, the Spectrum institute, ${ }^{24}$ as well as the participants of the Senior Fellows program, the Emerging Leaders Institute, and the ARL Leadership and Career Development Program.

\section{Notes}

1. Donald E. Riggs, "Academic Library Leadership: Observations and Questions," College \& Research Libraries 60 (Jan. 1999): 8.

2. "Leadership Development Programs: An Environmental Scan." Washington, D.C.: Association of Research Libraries Office of Leadership and Management Services. Unpublished document, 1.

3. Ibid.

4. Ibid.

5. Ibid., $1-2$.

6. "ACRL/Harvard Leadership Institute," College \& Research Libraries News 60 (Feb. 1999): 71.

7. For additional information on the ARL/LCDP, see ARL Diversity Program: Leadership and Career Development Program at http://www.arl.org/diversity/lcdp.html, or contact DeEtta Jones, ARL Program Officer for Diversity at <deetta@arl.org> or at 202- 296-2296. For information on the Emerging Leaders Institute, contact Emily Melton at: <emelton@ala.org>; or see Teresa Y. Neely, "Diversity Initiatives and Programs: The National Approach," Journal of Library Administration 27. Forthcoming publication.

8. Donna Brockmeyer-Klebaum, "Leadership Institutes: The Living Legacy They Can and Can't Leave," Feliciter 41 (Oct. 1995): 18.

9. F. William Summers and Lorraine Summers, “Library Leadership 2000 and Beyond: Snowbird Leadership Institute," Wilson Library Bulletin 66 (Dec. 1991): 38. 
Snowbird Leadership Institute 425

10. Ibid. 16.

11. Nancy Tessman, "Learning to Be Library Leaders," Wilson Library Bulletin 65 (Oct. 1990):

12. Ibid.

13. Summers and Summers, "Library Leadership 2000 and Beyond," 39.

14. Ibid., 40.

15. Marilyn L. Miller, “Snowbird: An Experiment in Leadership," American Libraries 23 (Oct. 1992): 812.

16. Summers and Summers, "Library Leadership 2000 and Beyond," 41.

17. Ibid.

18. Julie A. Brewer, "Post-Master's Residency Programs: Enhancing the Development of New Professionals and Minority Recruitment in Academic and Research Libraries," College \& Research Libraries 58 (Nov. 1997): 528-37.

19. Ibid., 531.

20. Mark D. Winston, "The Recruitment, Education and Careers of Academic Business Librarians" (Ph.D. diss., Univ. of Pittsburgh, 1997).

21. The Snowbird Leadership Institute listserv is open only to Snowbird participants, mentors, and administrators. To be added to the list, contact Mike Silvia at msilvia@etal.uri.edu.

22. For information on the Snowbird Leadership Institute, contact Bobbi Bohman, Salt Lake City Public Library, Salt Lake City, Utah. In 1997, a "reunion" institute was held for participants from earlier years, rather than the usual institute. Thus, respondents were asked to complete the instrument on the basis of their first participation in the institute.

23. Includes double majors, international affairs, and American studies.

24. See the Spectrum Initiative Mission at http://www.ala.org/spectrum/mission.html, and also, Spectrum Initiative: Scholarship Requirements \& Expectations at http://www.ala.org/spectrum/mission.html. 